\title{
Cultivation of a novel cold-adapted nitrite oxidizing betaproteobacterium from the Siberian Arctic
}

\author{
Mashal Alawi ${ }^{1}$, André Lipski ${ }^{2}$, Tina Sanders ${ }^{1}$, Eva-Maria-Pfeiffer ${ }^{3}$ and Eva Spieck ${ }^{1}$ \\ ${ }^{1}$ Department of Biology, Biocenter Klein Flottbek, University of Hamburg, Hamburg, Germany; ${ }^{2}$ Department \\ of Microbiology, Fachbereich Biologie/Chemie, University of Osnabrück, Osnabrück, Germany and \\ ${ }^{3}$ Department of Geowissenschaften, Institute of Soil Science, University of Hamburg, Hamburg, Germany
}

\begin{abstract}
Permafrost-affected soils of the Siberian Arctic were investigated with regard to identification of nitrite oxidizing bacteria active at low temperature. Analysis of the fatty acid profiles of enrichment cultures grown at $4^{\circ} \mathrm{C}, 10^{\circ} \mathrm{C}$ and $17^{\circ} \mathrm{C}$ revealed a pattern that was different from that of known nitrite oxidizers but was similar to fatty acid profiles of Betaproteobacteria. Electron microscopy of two enrichment cultures grown at $10^{\circ} \mathrm{C}$ showed prevalent cells with a conspicuous ultrastructure. Sequence analysis of the 16S rRNA genes allocated the organisms to a so far uncultivated cluster of the Betaproteobacteria, with Gallionella ferruginea as next related taxonomically described organism. The results demonstrate that a novel genus of chemolithoautotrophic nitrite oxidizing bacteria is present in polygonal tundra soils and can be enriched at low temperatures up to $17^{\circ} \mathrm{C}$. Cloned sequences with high sequence similarities were previously reported from mesophilic habitats like activated sludge and therefore an involvement of this taxon in nitrite oxidation in nonarctic habitats is suggested. The presented culture will provide an opportunity to correlate nitrification with nonidentified environmental clones in moderate habitats and give insights into mechanisms of cold adaptation. We propose provisional classification of the novel nitrite oxidizing bacterium as 'Candidatus Nitrotoga arctica'.
\end{abstract}

The ISME Journal (2007) 1, 256-264; doi:10.1038/ismej.2007.34; published online 7 June 2007

Subject Category: microbial ecology and functional diversity of natural habitats

Keywords: cold adaptation; nitrification; nitrite oxidation; permafrost

\section{Introduction}

Nitrification - the biological oxidation of ammonia to nitrite and further to nitrate is of fundamental importance for the global nitrogen cycle in marine and terrestrial habitats. It is a two-step, aerobic process performed by ammonia and nitrite oxidizing bacteria. Nitrite has a central position in the nitrogen cycle, connecting aerobic and anaerobic pathways. Nitrite oxidizing bacteria play a major role in removing nitrite from the environment because it is toxic for living organisms (Philips et al., 2002). If the linkage of nitrification and denitrification is disturbed, elevated nitrite concentrations may accumulate. At low $\mathrm{pH}$, chemodenitrification is enhanced, which might stimulate $\mathrm{N}_{2} \mathrm{O}$ emission to the atmosphere.

Correspondence: Dr E Spieck, Department of Biology, Biocenter Klein Flottbek, University of Hamburg, Ohnhorststr. 18, 22609 Hamburg, Germany.

E-mail: spieck@mikrobiologie.uni-hamburg.de

Received 26 February 2007; revised and accepted 21 April 2007; published online 7 June 2007
Traditionally, classification of nitrifying bacteria is based on cell shape and ultrastructural criteria (Watson et al., 1989). Nitrite oxidizers catalyzing the second step of nitrification are so far restricted to four genera with eight described species. They are phylogenetically affiliated to the Alpha-, Gamma-, provisionally Deltaproteobacteria and the deep-branching bacterial phylum Nitrospirae (Spieck and Bock, 2005). Nitrifying bacteria are fastidious and slowgrowing organisms, but their cultivation and isolation is indispensable to assign functions with sequence data obtained by direct molecular methods.

Temperature is one of the relevant factors influencing nitrification in nature with regard to activity as well as community structure (Avrahami and Conrad, 2003). Most of the described ammonia and nitrite oxidizing bacteria have a temperature optimum of about $28^{\circ} \mathrm{C}$ (Watson et al., 1989), increasing to $39^{\circ} \mathrm{C}$ in the case of Nitrospira moscoviensis (Ehrich et al., 1995). The temperature range for growth of nitrifying bacteria varies from $-5^{\circ} \mathrm{C}$ (Jones and Morita, 1985) to about $60^{\circ} \mathrm{C}$ (Lebedeva et al., 2005).

The finding of marine crenarchaeota with the capability to oxidize ammonia (Könneke et al., 2005) 
indicated recently that nitrifying organisms are more diverse than previously assumed. Potential sources for novel nitrifying bacteria are extreme habitats like permafrost-affected soils, which are characterized by a low temperature mean and extreme temperature regimes $\left(+25^{\circ} \mathrm{C}\right.$ to $\left.-45^{\circ} \mathrm{C}\right)$ during seasonal freezing and thawing (Wagner et al., 2005). Little is known about the distribution of nitrifying bacteria in this environment (Lebedeva and Soina, 1994; Wagner et al., 2001). Cultivation approaches performed at $28^{\circ} \mathrm{C}$ with $3 \mathrm{~mm}$ substrate revealed the coexistence of Nitrobacter and Nitrospira in a soil sample derived from the rim of a low-centered polygon on Samoylov Island, Lena Delta, in a depth of 8-11 cm (Bartosch et al., 2002). In this study, enrichment of nitrite oxidizing bacteria was performed at low temperatures in accordance with the in situ conditions. Maximum soil temperature of the active layer in a depth of $7 \mathrm{~cm}$ on Samoylov Island amounted to $11.4^{\circ} \mathrm{C}$ in August 2001 (Kobabe et al., 2004).

\section{Materials and methods}

Investigation site

The study site is located in the youngest part of the Lena Delta on Samoylov Island (N $72^{\circ} 22$, E $\left.126^{\circ} 28\right)$. In this zone of continuous permafrost, a mean annual air temperature of $-11.9^{\circ} \mathrm{C}$ was measured between 2001 and 2003 (Liebner and Wagner, 2007). The island is characterized by a pattern of lowcentered ice-wedge polygons. Typical $\mathrm{C} / \mathrm{N}$ values for the polygon rim are 16-18 and 31-37 for the wet polygon center (Kobabe et al., 2004). A total of nine samples was taken in August 2001 in a depth of $0-5 \mathrm{~cm}$ as a transect from the rim to the center (6675-6683) with a distance of $50 \mathrm{~cm}$. Soil material was transported to Germany in a frozen state.

\section{Culturing}

Initially, $1 \mathrm{~g}$ of soil material was inoculated into $10 \mathrm{ml}$ of mineral medium for nitrite oxidizing bacteria (Ehrich et al., 1995) with a substrate concentration of $0.3 \mathrm{mM}$. For plating, the lithoautotrophic medium with $3 \mathrm{~mm}$ nitrite and agarose $\left(15 \mathrm{gl}^{-1}\right)$ was used. Parallel incubations were performed at $4^{\circ} \mathrm{C}, 10^{\circ} \mathrm{C}$ and $17^{\circ} \mathrm{C}$. Consumption of nitrite was regularly checked by the Griess-Ilosavay spot test and replaced in the case of growth. Upscaling was performed as described (Spieck et al., 2006) to get a sufficient cell amount for further analysis. Purity tests were performed and modified by Steinmüller and Bock (1976).

\section{Chemical analyses}

Nitrite and nitrate concentrations were determined by ion-pair chromatography with a Hypersil ODS C18 column $(125 \times 4.6 \mathrm{~mm})$ (Meincke et al., 1992) followed by UV detection in an automated system (Kontron, Eching, Germany).
Electron microscopy

For observation by electron microscopy cells were collected at 13000 r.p.m., fixed with $2.5 \%(\mathrm{v} / \mathrm{v})$, glutaraldehyde and $2 \%(\mathrm{w} / \mathrm{v})$ osmium tetroxide and embedded in Epon 812 (Serva) according to a previously published protocol (Spieck et al., 2006). Examination was carried out with a transmission electron microscope (Zeiss model Leo 906E with a CCD camera model 794).

Fluorescence in situ hybridization and immunofluorescence labeling

Cells were collected and fixed in $3 \%$ paraformaldehyde as described by Bartosch et al. (1999). Fluorescent in situ hybridization (FISH) was performed according to the same protocol with the oligonucleotide probe Bet 42a (Manz et al., 1992). For identification of the novel betaproteobacterium, hybridization was carried out with the Cy3-labeled oligonucleotide NTG840 (see below) using a formamide concentration of $10-20 \%$.

The nitrite oxidizing cells were detected with antibodies against their key enzyme by immunofluorescence (IF) labeling. Harvested cells were incubated with the antibodies Hyb 153-3 and Cy3-labeled secondary antibodies (Biotrend, Köln, Germany) (Bartosch et al., 1999). Control preparations without primary antibodies were included in every experiment. To detect total cells, samples were stained with 4',6-diamidino-2-phenylindole (Dapi) at a concentration of $10 \mu \mathrm{g} \mathrm{ml}^{-1}$ for $5 \mathrm{~min}$. Dapi staining was visualized by Leica filter set A (BP 340-380 exc; RKP 400; LP 425 em.). Cy3 labeling was visualized by Leica filter set N 2.1 (BP 515-560 exc; RKP 580; LP 590 em.).

\section{Analysis of the fatty acids}

Biomass for fatty acid extraction was obtained from large-scale enrichments grown in $1.5 \mathrm{l}$ medium in $3 \mathrm{l}$ Erlenmeyer flasks. Cultures were incubated without stirring for 2-6 months and regularly fed with sterile nitrite solution. When dense flocs of nitrite oxidizing bacteria had developed, cells were harvested by centrifugation, washed in $0.9 \%(\mathrm{w} / \mathrm{v}) \mathrm{NaCl}$ and stored at $-20^{\circ} \mathrm{C}$. Preparation of fatty acid methyl esters and gas chromatographic analyses of the extracts were performed as described previously (Spieck et al., 2006).

$16 S$ rRNA gene sequence and phylogenetic analysis The partial 16S rDNA fragments were amplified by PCR with the eubacterial primer set $341 \mathrm{~F} / 907 \mathrm{R}$ (Muyzer et al., 1998). As usual for TGGE/DGGE analysis, a GC-clamp was added to the forward primer. Denaturing gradient gel electrophoresis (DGGE) (Muyzer et al., 1998) was performed with a gradient from $50 \%$ to $80 \%$ denaturants and the temperature was $59^{\circ} \mathrm{C}$. Bands were extracted from 
the gel, reamplified and the partial $165 \mathrm{rDNA}$ sequences were compared with those on publicly accessible databases by using the program Basic Local Alignment Search Tool (BLAST, NCBI; Altschul et al., 1990). By the use of the program package ARB (Ludwig et al., 2004), a neighborjoining tree was generated from an alignment of $16 \mathrm{~S}$ rDNA sequences from selected Betaproteobacteria and the nitrite oxidizing enrichment culture 6680 .

\section{Cloning of the 165 rDNA}

The 16S rRNA genes were amplified by the bacterial conserved primers $27 \mathrm{~F}$ and $1492 \mathrm{R}$. The PCR product was directly ligated into the pGEM-T vector cloning system (Promega, Mannheim, Germany) and transformed into competent cells as described in the manufacturer's instructions. For partial and nearcomplete sequencing of clone inserts, the plasmid primer SP6 and T7 were used to reamplify the insert. A range of bacterial conserved primers (341F/R, 517F/R, 907F/R, 1017F/R) were used for sequencing (Lane, 1991).
Specific PCR/specific oligonucleotide probe

On the basis of the newly retrieved 16S rDNA sequence of the novel betaproteobacterium (culture 6680), a new specific primer set and probe were constructed (NTG200F ${ }^{\prime}$-ctcgcgttttcggagcgg $3^{\prime}$ and NTG840R $5^{\prime}$-ctaaggaagtctcctccc $3^{\prime}$ ). The specificity was evaluated by using the program BLAST (NCBI) and Probe Match (RDP-II, Cole et al., 2007). The PCR conditions were as follows: step $196^{\circ} \mathrm{C} 2 \mathrm{~min}$, step 2 $58^{\circ} \mathrm{C} 50 \mathrm{~s}$, step $372^{\circ} \mathrm{C} 50 \mathrm{~s}$, step 4 final elongation $4 \mathrm{~min}$. Steps 2 and 3 were repeated 28 times.

\section{Results and discussion}

Enrichment of the novel nitrite oxidizing bacterium The investigation site, located on Samoylov Island in the Lena Delta, is characterized by a microrelief of ice-wedge polygons, with a depressed wet center and an elevated dryer rim (Kobabe et al., 2004). Selective enrichment of nitrite oxidizing bacteria was successfully performed from all nine soils of a polygon transect with incubation temperatures of

Table 1 Fatty acid profiles of Candidatus Nitrotoga arctica (culture 6678) derived from the active layer of permafrost soil, grown at $4{ }^{\circ} \mathrm{C}$, $10^{\circ} \mathrm{C}$ and $17^{\circ} \mathrm{C}$. Profiles based on pure cultures of known nitrite oxidizing genera and Nitrospira enrichment cultures are shown for comparison (adapted from Lipski et al. (2001) and Spieck et al. (2006))

\begin{tabular}{|c|c|c|c|c|c|c|c|c|}
\hline & \multicolumn{3}{|c|}{$\begin{array}{c}\text { Candidatus } \\
\text { Nitrotoga } \\
\text { arctica } \\
\text { Temperature }\left({ }^{\circ} \mathrm{C}\right)\end{array}$} & \multirow[t]{2}{*}{ Nitrobacter } & \multirow[t]{2}{*}{ Nitrococcus } & \multirow[t]{2}{*}{ Nitrospina } & \multirow[t]{2}{*}{ Nitrospira } & \multirow[t]{2}{*}{$\begin{array}{l}\text { Nitrospira } \\
\text { enrichment } \\
\text { cultures }^{a}\end{array}$} \\
\hline & 4 & 10 & 17 & & & & & \\
\hline \multicolumn{9}{|l|}{ Fatty acid (\%) } \\
\hline 10:0 3OH & 2.3 & 2.7 & 3.5 & & & & & $0-1$ \\
\hline $12: 0$ & 3.8 & 5.0 & 5.9 & & & & $0-1$ & \\
\hline $12: 03 \mathrm{OH}$ & 3.5 & 5.3 & 6.2 & & $0-1$ & & & \\
\hline $14: 1$ cis 9 & & & & & & $2-9$ & & \\
\hline $14: 0$ & 1.7 & 2.0 & 3.1 & $0-1$ & $0-1$ & $30-32$ & $0-1$ & $2-7$ \\
\hline $15: 0$ iso & 1.3 & 1.9 & 2.9 & & & & & $0-2$ \\
\hline 15:0 anteiso & & 0.8 & 1.4 & & & & & $0-1$ \\
\hline $15: 0$ & & & & & & $0-1$ & $0-1$ & \\
\hline $14: 02 \mathrm{OH}$ & 3.1 & 4.6 & 5.0 & & & & & \\
\hline 14:0 3OH & 0.5 & 0.6 & 1.4 & & & & & $0-1$ \\
\hline 16:0 iso & & & 0.7 & & & & & $1-2$ \\
\hline $16: 1$ cis 7 & & 0.8 & 1.3 & & & & $5-34$ & $3-18$ \\
\hline $16: 1$ cis 9 & 46.7 & 38.8 & 24.4 & $0-4$ & $12-31$ & $46-54$ & $0-3$ & $1-2$ \\
\hline 16:1 trans $9 / 16: 1$ cis 10 & 0.6 & 0.5 & 0.6 & & & $0-7$ & & \\
\hline $16: 1$ cis 11 & & 0.8 & & & & $0-1$ & $16-36$ & $0-42$ \\
\hline $16: 0$ & 21.7 & 22.5 & 26.1 & $6-14$ & $23-30$ & $4-7$ & $20-38$ & $16-52$ \\
\hline 16:0 11methyl & & & & & & & $0-34$ & $0-21$ \\
\hline $17: 0$ iso & 0.5 & 0.6 & & & & & & \\
\hline 17:0 anteiso & 0.5 & 0.3 & 0.7 & & & & & \\
\hline $17: 1$ cis 9 & & & & $0-1$ & & & & \\
\hline $16: 03 \mathrm{OH}$ & & & & & & $1-3$ & $0-1$ & $1-3$ \\
\hline $17: 0$ & & & & $0-1$ & & & $0-1$ & \\
\hline 17:0 cyclo9-10 & 4.1 & 5.3 & 5.2 & & $1-2$ & $1-2$ & & \\
\hline 18:1 cis 9 & 1.5 & 1.2 & 1.3 & $0-2$ & & & $0-2$ & $0-1$ \\
\hline 18:1 cis 11 & 5.1 & 3.8 & 5.2 & $72-92$ & $42-51$ & $0-1$ & $0-1$ & $0-5$ \\
\hline $18: 0$ & 3.0 & 1.3 & 2.9 & $0-2$ & $1-3$ & $0-1$ & $0-9$ & $1-3$ \\
\hline $18: 1$ cis 11 11methyl & & 0.4 & 0.9 & & & & & \\
\hline $17: 0$ iso $3 \mathrm{OH}$ & & 0.6 & 1.1 & & & & & \\
\hline 18:0 10methyl & & & & & & & & $0-1$ \\
\hline 19:0 cyclo11-12 & & & & $0-16$ & $0-2$ & & & $0-2$ \\
\hline
\end{tabular}

ancluding cultures Ns $\left(42^{\circ} \mathrm{C}\right)$, Ns $\left(47^{\circ} \mathrm{C}\right)$ and 'Candidatus Nitrospira defluivi'. 

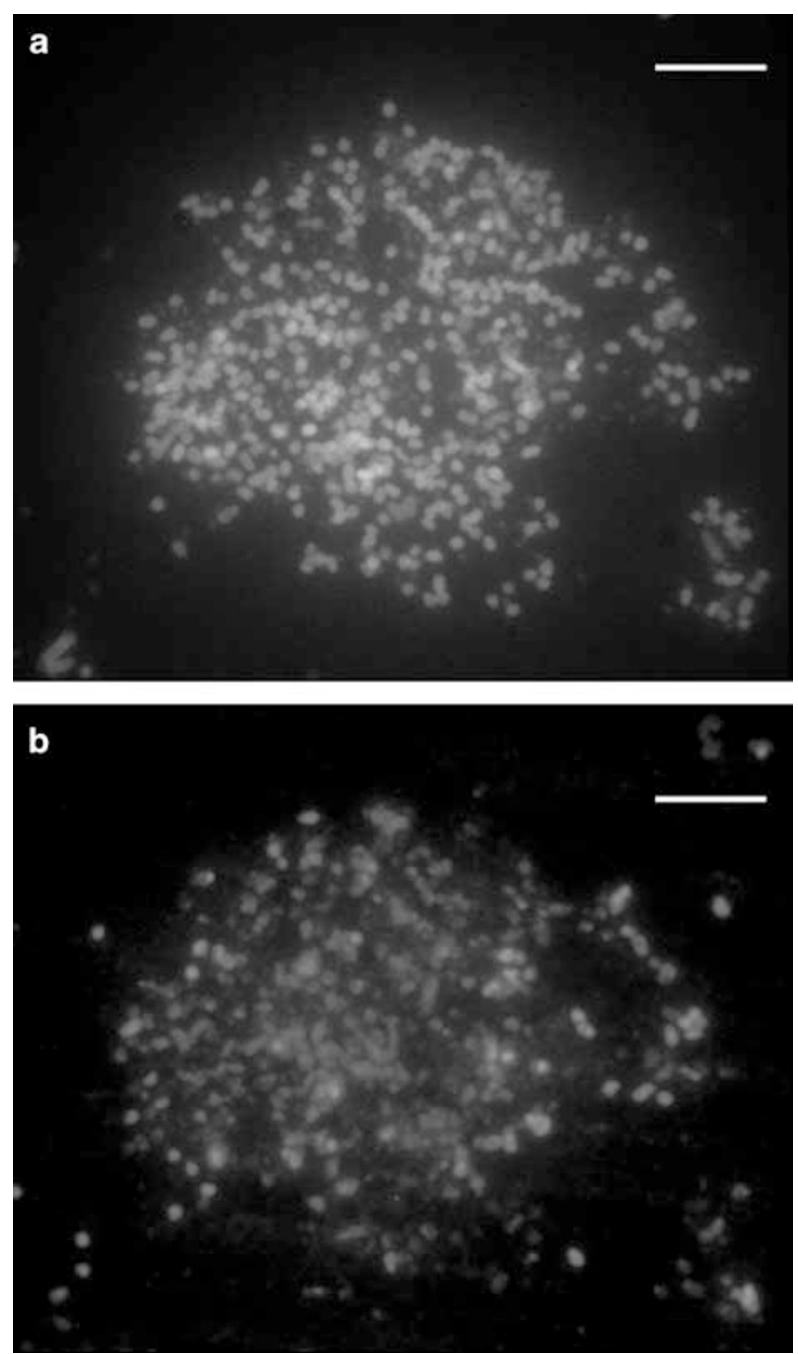

Figure 1 Immunofluorescence labeling of culture 6678 incubated at $10^{\circ} \mathrm{C}$. Coccoid to rod-shaped cells were recognized by monoclonal antibodies against the $\beta$-subunit of the nitrite oxidoreductase. (a) Staining with Dapi as control. (b) Labeling with Hyb 153-3. Bars $=20 \mu \mathrm{m}$.

$4^{\circ} \mathrm{C}, 10^{\circ} \mathrm{C}$ and $17^{\circ} \mathrm{C}$ using $0.3 \mathrm{mM}$ nitrite. Following the protocol for the enrichment of a slow-growing Nitrospira strain (Spieck et al., 2006), permafrost cultures were regularly supplemented with additional substrate, when it was consumed. The highest degree of enrichment of nitrite oxidizing bacteria in relation to the total cell number was achieved in culture 6680, which was purified by plating on lithoautotrophic nitrite agar.

\section{Physiological investigations of nitrite oxidizing enrichment cultures}

To prove cold adaptation of the nitrite oxidizers obtained from permafrost-affected soils, growth of one enrichment culture (6678), originating from the polygon slope, was investigated in lithoautotrophic medium. Using $4^{\circ} \mathrm{C}$ for incubation, $0.9 \mathrm{~mm}$ nitrite was oxidized stoichiometrically to nitrate in about
1 month (not shown). In contrast, no growth was detected at an incubation temperature of $25^{\circ} \mathrm{C}$. In control experiments at $4^{\circ} \mathrm{C}$ with different strains of Nitrobacter and Nitrospira $3 \mathrm{~mm}$ respectively $0.3 \mathrm{mM}$ nitrite were not consumed within 2 months.

\section{Chemotaxonomic analysis}

Nitrite oxidizing bacteria are scattered in different subclasses of the phylogenetic tree, which is reflected in great variances of the fatty acid profiles (Lipski et al., 2001). Recently, chemotaxonomic analysis was successful in separating a new species of Nitrospira enriched from activated sludge (Spieck et al., 2006) from known species of this genus. Here, this method was used for the initial characterization of nitrite oxidizing enrichments originating from the Siberian Arctic. The fatty acid profile of the permafrost culture 6678 grown at $4^{\circ} \mathrm{C}, 10^{\circ} \mathrm{C}$ and $17^{\circ} \mathrm{C}$ was characterized by three hydroxy compounds (10:0 $3 \mathrm{OH}, 12: 03 \mathrm{OH}$ and 14:0 2OH) in combination with 16:0 and 16:1 cis 9 as major lipids (Table 1). This profile is clearly different from all nitrite oxidizing bacteria detected till now. In contrast to culture 6678, the long-chain fatty acid 18:1 cis 11 as dominating compound is typical for the genera Nitrobacter and Nitrococcus, whereas the marine genus Nitrospina can be differentiated by high amounts of the short-chain lipid 14:0. The genus Nitrospira including the Nitrospira dominated enrichment cultures Ns $\left(42^{\circ} \mathrm{C}\right)$, Ns $\left(47^{\circ} \mathrm{C}\right)$ and 'Candidatus Nitrospira defluvii' contain the fatty acid 16:1 cis 7 in combination with 16:1 cis 11 and/ or 16:0 11methyl (Lipski et al., 2001; Spieck et al., 2006). These chemotaxonomic markers were almost absent in the enrichment culture 6678. Our results suggested the existence of one so far unknown lowtemperature-adapted nitrite oxidizer. The adaptation is obviously realized by increasing the percentage of 16:1 cis 9 with decreasing temperature (Table 1), which is a strategy already described for ammonia oxidizing bacteria (Jones and Prahl, 1985) and bacterial isolates from permafrost soils (Ponder et al., 2005). Further enrichment cultures 6679, 6680 and 6681 incubated at $4^{\circ} \mathrm{C}, 10^{\circ} \mathrm{C}$ or $17^{\circ} \mathrm{C}$ resulted in this typical pattern for Betaproteobacteria with 16:0 and 16:1 cis 9 as dominating compounds, too (not shown). From these enrichments, only from culture 6675 (derived from the dryer polygon rim) grown at $17^{\circ} \mathrm{C}$, a fatty acid pattern (16:0 and $16: 1$ cis 11$)$ in the Nitrospira range was obtained (not shown), corresponding to that of 'Candidatus Nitrospira defluvii' (Spieck et al., 2006).

Identification of cold-adapted nitrite oxidizing bacteria with monoclonal antibodies

Results of fluorescence microscopic analysis using Dapi revealed that nearly all cells of the enrichment culture 6678 grown at $10^{\circ} \mathrm{C}$ appeared as irregular coccoid cells occurring in dense aggregates 

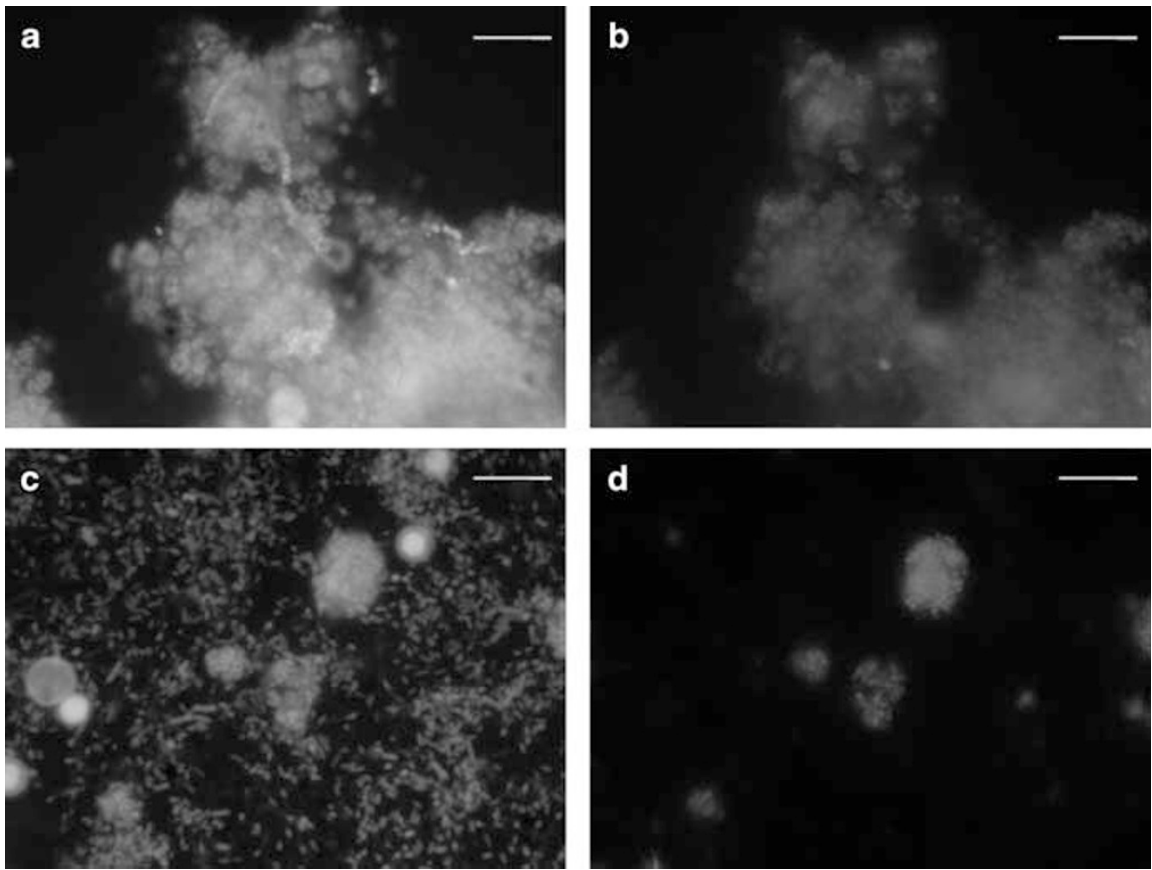

Figure 2 Fluorescence in situ hybridization (FISH) analysis of the enrichment culture 6678 grown at $10^{\circ} \mathrm{C}(\mathbf{a}, \mathbf{b})$ or $17^{\circ} \mathrm{C}(\mathbf{c}, \mathbf{d})$. Epifluorescence micrographs of Dapi-stained cells (a, c). Specific labeling of the cells with the oligonucleotide probe Bet 42a, recognizing Betaproteobacteria (b, d). Bars $=20 \mu \mathrm{m}$.

(Figure 1a). This morphology is not typical for one of the known genera in this bacterial group, but resembles the marine genus Nitrococcus. Functional identity of such cells as nitrite oxidizers was confirmed with monoclonal antibodies recognizing the key enzyme of nitrite oxidation (Aamand et al., 1996). The antibody Hyb 153-3 was shown to detect all known representatives of nitrite oxidizing bacteria specifically (Bartosch et al., 1999) and therefore offers a high potential for recognition of novel nitrite oxidizers. As shown in Figure 1a and b, clear reaction of the monoclonal antibodies with the coccoid cells became visible.

\section{FISH}

The results of fatty acid profiling shown above, revealed that most of the bacteria enriched in lithoautotrophic media with nitrite as energy source belong to Betaproteobacteria. To prove identity of the enriched coccoid cells, FISH was applied using the oligonucleotide probe Bet 42a targeting Betaproteobacteria, one of the major bacterial groups in Siberian tundra soils (Kobabe et al., 2004). Labeling was nearly complete in culture 6678 grown at $10^{\circ} \mathrm{C}$ where coccoid cells dominated (Figure 2a and b). At long-term incubation for 4 years at $17^{\circ} \mathrm{C}$, the amount of the signal decreased drastically and only a few aggregates of coccoid cells were labeled (Figure 2c and d). Dominating rods, belonging to heterotrophic bacteria as shown by purity tests, were not labeled with probe Bet 42a.
Ultrastructure of the novel nitrite oxidizing bacteria Nitrifying bacteria can be taxonomically classified on the genus level by their morphology and ultrastructure, for example, by the presence or absence of intracytoplasmic membranes. Striking differences in ultrastructure to the known genera of nitrite oxidizing bacteria became obvious when ultrathin sections of cultures 6678 and 6680 grown at $10^{\circ} \mathrm{C}$ were investigated by electron microscopy (Figure 3a). A longish cytoplasm was surrounded by an extraordinary wide periplasmic space at the longitudinal axis resulting in an irregular coccoid overall appearance. In cross-sections, cells gave the impression of 'fried eggs'. Cytoplasmic and outer membrane were not in close contact at the longitudinal axis like in most other Gram-negative bacteria, but cells showed a balloon-like periplasmic space (Figure 3b). An unusual wide periplasmic space was already described for members of the genus Nitrospira (Watson et al., 1986), but the dimensions were more extended here. No intracytoplasmic membranes or carboxysomes were found. Cells had an overall diameter of $0.4-0.7 \mu \mathrm{m}$ and a maximal length of $1.0 \mu \mathrm{m}$.

\section{Analysis of the nitrite oxidizing enrichments by DGGE profiles}

To classify nitrite oxidizers in the enrichment cultures $6675,6678,6679$ and 6680 grown at $10^{\circ} \mathrm{C}$ or $17^{\circ} \mathrm{C}$, molecular studies were performed. DNA was extracted, the $16 \mathrm{~S}$ rDNA fragments were 

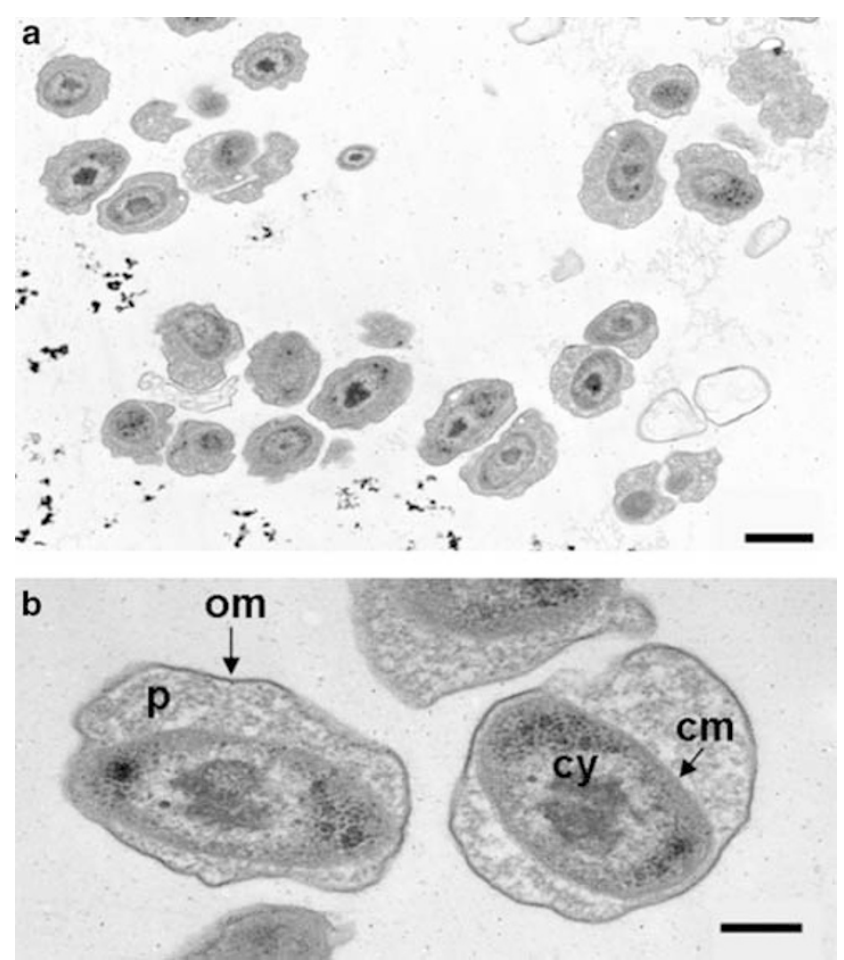

Figure 3 Electron micrographs of ultrathin sections of the nitrite oxidizing enrichment culture 6678 grown at $10^{\circ} \mathrm{C}$. (a) Overview of the dominant cell type with an unique ultrastructure. Bar $=500 \mathrm{~nm}$. (b) A longish cytoplasm is surrounded by an extraordinary wide periplasmic space. Cy $=$ cytoplasm, $\mathrm{cm}=$ cytoplasmic membrane, om $=$ outer membrane, $\mathrm{P}=$ periplasm. Bar $=200 \mathrm{~nm}$.

amplified with the eubacterial primer set $341 \mathrm{~F} / 907 \mathrm{R}$ and separated by DGGE. In DNA extracted from culture 6680, only one clear band was obvious in the gel (Figure 4), although accompanying heterotrophic bacteria grow up in complex organic media. This band only occurred when the culture was grown chemolithoautotrophically (line 1) and was absent when the cells were supplied with organic substrates without addition of nitrite (line 2). Bands in the same range (lines 3-6) were found as dominating ones in DNA extracted from cultures $6675\left(17^{\circ} \mathrm{C}\right)$, $6678\left(17^{\circ} \mathrm{C}\right), 6679\left(17^{\circ} \mathrm{C}\right)$ and $6678\left(10^{\circ} \mathrm{C}\right)$. In contrast to culture 6678 cultivated for a few months at $17^{\circ} \mathrm{C}$, the unique DNA band became very weak when the enrichment of the same soil sample was incubated at $17^{\circ} \mathrm{C}$ for 4 years (line 7). Simultaneously other bands indicating the presence of potential heterotrophic bacteria appeared. Accordingly, in electron microscopic investigations of culture 6678 grown at $17^{\circ} \mathrm{C}$, the percentage of coccoid cells was reduced drastically and different cell types of bacteria, mostly in the form of rods, frequently occurred (not shown).

Following long-term incubation of the soil material, exclusively one weak Nitrospira-like band (Figure 4, arrow) was detected and sequenced (enrichment 6675 at $17^{\circ} \mathrm{C}$ ). Here, the occurrence of
Nitrospira is in accordance with the detection of typical fatty acids for this genus mentioned above. However, DGGE analysis was performed 1 year later than chemotaxonomic analysis. As a consequence, the Nitrospira-like bacterium was overgrown by the typical betaproteobacterium (line 3).

$16 S$ rRNA gene sequence and phylogenetic analysis In DGGE analysis shown above, most nitrite oxidizing enrichments were dominated by the same DNA band. To clarify phylogeny of the bacterial source, bands belonging to the cultures 6678 and 6680 enriched at $10^{\circ} \mathrm{C}$ (Figure 4, lines 1+6) were extracted from the gel, reamplified and sequenced. Analysis of partial 16S rRNA gene sequences showed that both cultures were identical. They fell into a cluster of the betaproteobacteria, which consisted exclusively of cloned environmental samples. TA cloning was performed with culture 6680 and the almost complete sequence was obtained by the use of a range of several bacterial conserved primers. The sequence has been deposited in GenBank under the accession number DQ839562. Phylogenetic relationship between cloned sequences from the culture 6680 and representatives of the class Betaproteobacteria is shown in Figure 5. For the novel organism the name 'Candidatus Nitrotoga arctica' is proposed.

Comparative sequence analysis of the 16S rRNA genes revealed a high level of sequence identity between the new nitrite oxidizing betaproteobacterium and clone Run-S67 (AB247475) from domestic sewage (99.0\%), clone Elb 168 (AJ421928) from a biofilm of a polluted river (98.8\%) (Brümmer et al., 2003), clone BG.g12 (DQ228379) from subglacial environments (97.8\%) (Skidmore et al., 2005) and clone c5LKS43 (AM086129) from sediments of the mesotrophic lake Kinneret (96.3\%) (Schwarz et al., 2007). The next related taxonomically described organism is Gallionella ferruginea (93.5\% similarity).

\section{Development of a specific PCR/specific oligonucleotide probe}

To prove the correlation of the 16S rRNA sequence with the cells observed in light and electron microscopy, a specific oligonucleotide probe (NTG840) was designed. Using $10-20 \%$ formamide concentration, dominating coccoid cells following incubation at $10^{\circ} \mathrm{C}$ revealed a positive reaction (not shown). Additionally, a new specific primer set (NTG 200F/NTG 840R) for the novel betaproteobacterium was constructed and evaluated. Whereas the sequence of NTG200F is complementary to the sequences of the cultures 6678/6680 and the next three relatives (Figure 5), the primer/probe NTG840R also targets several environmental sequences inside the Betaproteobacteria. Analysis of natural samples (6676 and 6678) as well as $10^{\circ} \mathrm{C}$ enrichments of samples 6675, 6678, 6679, 6680, 


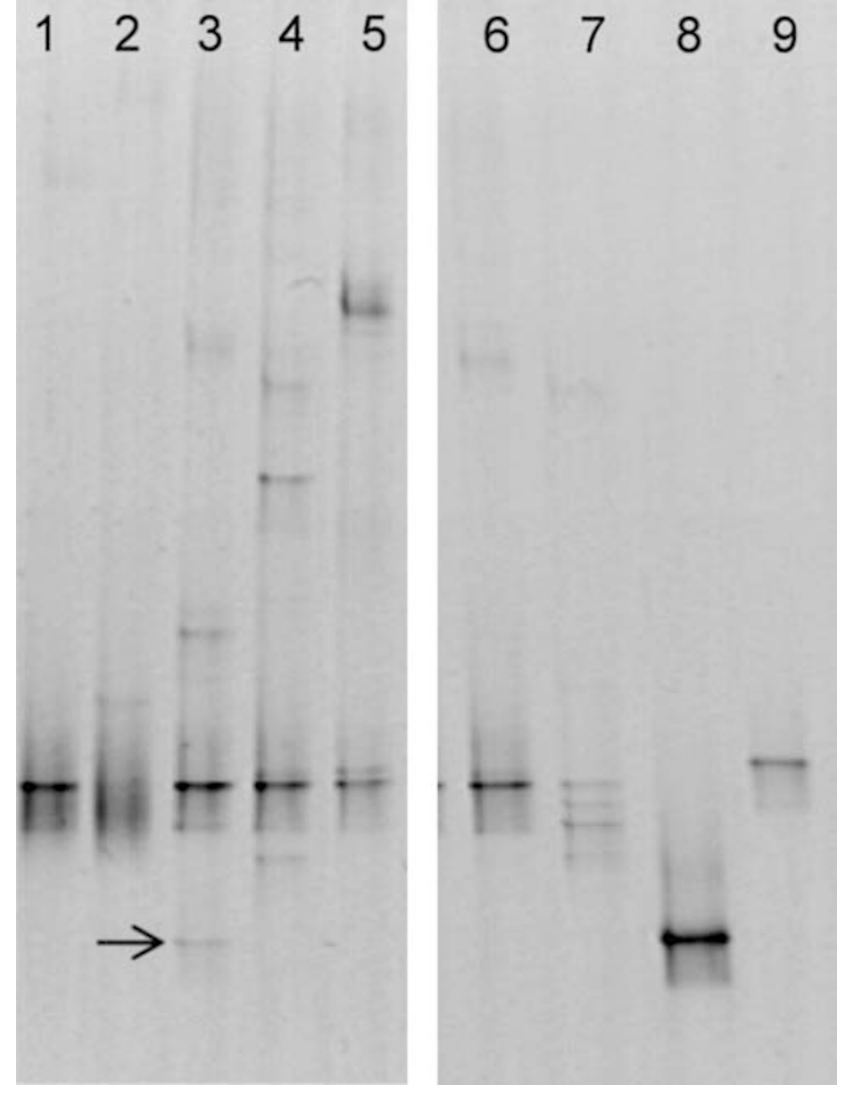

Figure 4 Denaturing gradient gel electrophoresis (DGGE) profile of nitrite oxidizing enrichment cultures derived from permafrost soil cultivated at $10^{\circ} \mathrm{C}$ or $17^{\circ} \mathrm{C}$. Line 1: culture 6680 grown lithoautotrophically at $10^{\circ} \mathrm{C}$; line 2 : culture 6680 grown with organic material; line 3: culture $6675\left(17^{\circ} \mathrm{C}\right)$; line 4: 6678 (shortterm incubation at $\left.17^{\circ} \mathrm{C}\right)$; line 5: $6679\left(17^{\circ} \mathrm{C}\right)$; line 6: $6678\left(10^{\circ} \mathrm{C}\right)$; line 7: 6678 (long-term incubation at $17^{\circ} \mathrm{C}$ ); line 8: pure culture of Nitrospira moscoviensis M1; line 9: pure culture of Nitrobacter hamburgensis X14. Arrow represents Nitrospira-like bacterium.

6681 and 6682 revealed that the new betaproteobacterium is detectable by this specific primer set (not shown).

\section{Ecological aspects}

Phylogenetic analyses of permafrost soils indicated that the majority of the clone sequences were $5-15 \%$ different from those in the current databases (Zhou et al., 1997). The results presented here enabled identification of one of the unknown genera and gave insight into its physiology and function, which remained unknown for most of the bacteria active in situ. On the basis of the first characteristics presented here, existence of an additional genus of nitrite oxidizing bacteria in polygonal tundra soil in Siberia is indicated. In contrast to terrestrial members of Nitrobacter and Nitrospira, cells of these Betaproteobacteria are well adapted to low temperatures. Our data suggest that this organism is active at temperatures up to $22^{\circ} \mathrm{C}$ and at very low nitrite concentrations ( $0.3 \mathrm{mM})$ in permafrost-affected soils. The finding of a so far unkown nitrite oxidizing bacterium is also important for moderate habitats like waste water treatment plants. Transfer of the preferred culture conditions to activated sludge in Dradenau, Hamburg revealed that the same organism is present, but has not been recognized before. Here, bacteria with nearly identical 16S rRNA sequence and ultrastructure were obtained when selective enrichment of nitrite oxidizing bacteria was performed at $10^{\circ} \mathrm{C}$ and not as usual at $28^{\circ} \mathrm{C}$. The ongoing activity of nitrifying bacteria at low temperature with simultaneous inhibition of heterotrophic bacteria (including denitrifiers) is of high relevance for biotechnology.

\section{Taxonomical considerations}

Based on the results of this study, we propose, according to Murray and Stackebrandt (1995), provisional classification of the novel nitrite oxidizing bacterium as 'Candidatus Nitrotoga arctica'. The short description of 'Candidatus Nitrotoga arctica' gen. nov, sp. nov is as follows:

Ni.tro.to'ga L.n. nitrum nitrate; L. fem.n. toga Roman outer garment. Arc.ti.ca named after the place where the organism was first discovered.

Coccoid cells to short rod-shaped cells with a size of $0.4-0.7 \times 1.0 \mu \mathrm{m}$. Periplasmic space is extraordinary wide, irregular bollooning over the longitudinal axis. Intracytoplasmic membranes and carboxysomes are absent. Gram-negative, non-motile. Multiplication by binary fission. Cells aggregate to flocs. Aerobic chemolithotroph metabolism with oxidation of nitrite to nitrate. Carbon dioxide is used as the sole carbon source. Non-marine. Growth range between $4^{\circ} \mathrm{C}$ and $22^{\circ} \mathrm{C}$ with an optimum at $10^{\circ} \mathrm{C}$. Adapted to low nitrite concentrations ( $0.3 \mathrm{mM})$ with a tolerance limit of $1.2 \mathrm{mM}$.

Dominating fatty acids are 16:1 cis 9 and 16:0. Hydroxy fatty acids 10:0 3OH, 12:0 3OH and 14:0 $2 \mathrm{OH}$ are present. Phylogenetically assigned to the Betaproteobacteria based on 16S rRNA gene sequences (accession no. DQ839562). Not isolated.

Habitat: active layer of permafrost-affected soils in the Siberian Arctic. Cells with nearly identical ultrastructure and 16S rRNA gene sequence were also detected in activated sludge from a municipal waste water treatment plant in Hamburg, Germany.

\section{Perspective}

Isolation of the novel nitrite oxidizing organism is in progress, which will enable investigations of physiological aspects like organotrophic growth and the capability for nitrate reduction. Correlation of structure and function is another main point with regard to the conspicuous ultrastructure. Molecular and biological studies will focus on the detection in environmental samples and distribution patterns of the different genera of nitrite oxidizing bacteria. 


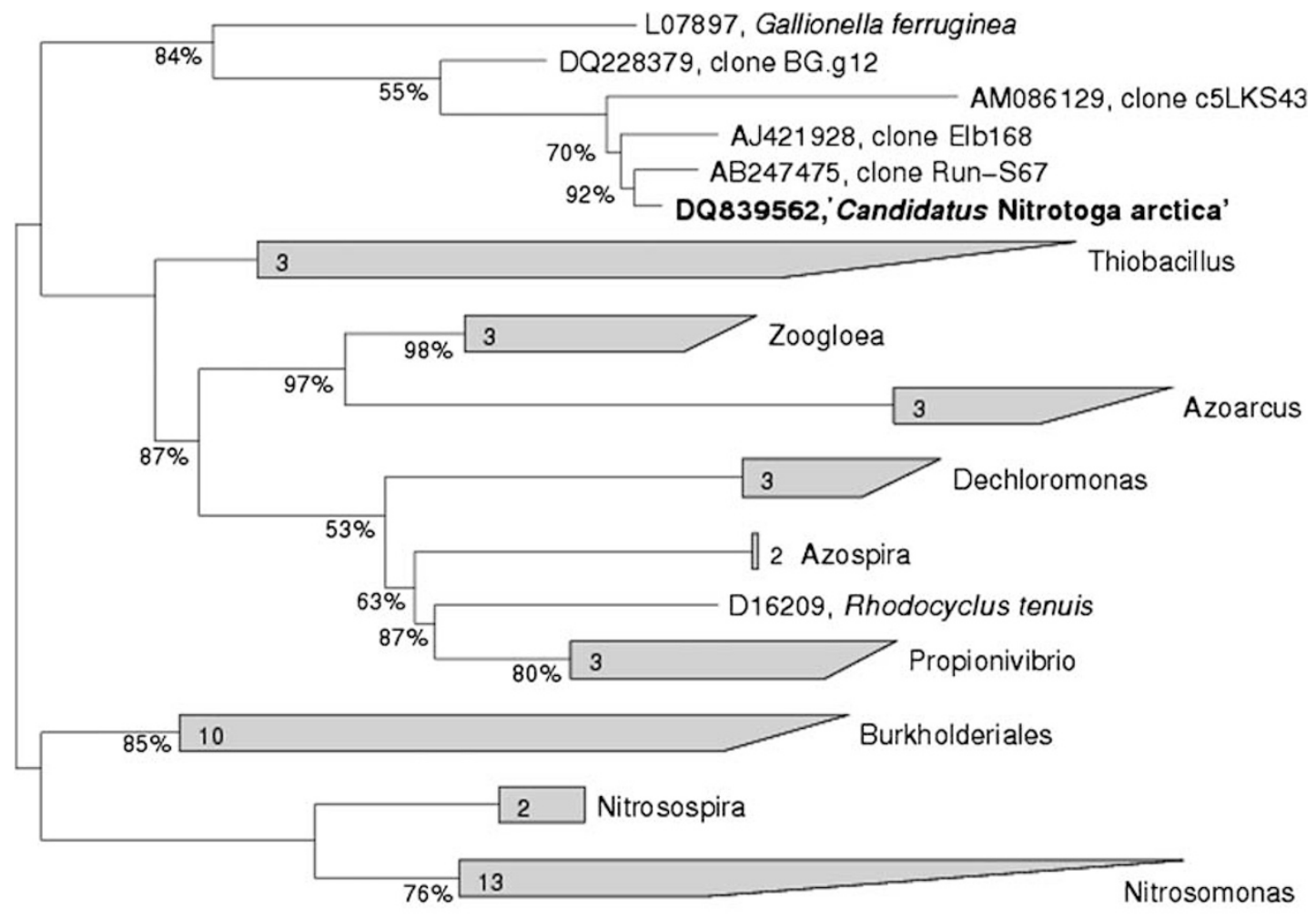

0.01

Figure 5 Phylogenetic relationships between the cloned 16S rRNA sequence from the nitrite oxidizing culture 6680 ('Candidatus Nitrotoga arctica') and representatives of the Betaproteobacteria. The tree was constructed using the neighbor-joining algorithm. Notes supported by bootstrap values are indicated.

\section{Acknowledgements}

Sampling was kindly performed by D Wagner (AWI Potsdam) in frame of the German-Russian cooperation 'System Laptev Sea'. We thank I Wachholz for technical help in electron microscopy, P-G Jozsa for chemical analysis by HPLC-technique and M Kaya for culturing nitrite oxidizers from activated sludge. FISH analysis was kindly supported by C Hartwig. Laboratory assistance was provided by M Klimova (Voronezh State University) in the frame of a DAAD exchange programe. This research was funded by the BMBF Russian-German Cooperation 'Laptev Sea System: Process Studies on Permafrost Dynamics in the Laptev Sea'.

\section{References}

Aamand J, Ahl T, Spieck E. (1996). Monoclonal antibodies recognizing nitrite oxidoreductase of Nitrobacter hamburgensis, N. winogradskyi, and N. vulgaris. Appl Environ Microbiol 62: 2352-2355.

Altschul SF, Gish W, Miller W, Myers EW, Lipman DJ. (1990). Basic local alignment search tool. J Mol Biol 215: $403-410$.

Avrahami S, Conrad R. (2003). Patterns of community change among ammonia oxidizers in meadow soils upon long-term incubation at different temperatures. Appl Environ Microbiol 69: 6152-6164.
Bartosch S, Hartwig C, Spieck E, Bock E. (2002). Immunological detection of Nitrospira-like bacteria in various soils. Microb Ecol 43: 26-33.

Bartosch S, Wolgast I, Spieck E, Bock E. (1999). Identification of nitrite oxidizing bacteria with monoclonal antibodies recognizing the nitrite oxidoreductase. Appl Environ Microbiol 65: 4126-4133.

Brümmer IHM, Felske A, Wagner-Döbler I. (2003). Diversity and seasonal variability of $\beta$-Proteobacteria in Biofilms of polluted rivers: analysis by temperature gradient gel electrophoresis and cloning. Appl Environ Microbiol 69: 4463-4473.

Cole JR, Chai B, Farris RJ, Wang Q, Kulam-Syed-Mohideen AS, McGarrell DM et al. (2007). The ribosomal database project (RDP-II): introducing myRDP space and quality controlled public data. Nucleic Acids Res 35(database issue): D169-D172; doi:10.1093/nar/ gkl889.

Ehrich S, Behrens D, Lebedeva E, Ludwig W, Bock E. (1995). A new obligately chemolithoautotrophic, nitrite oxidizing bacterium, Nitrospira moscoviensis sp: nov and its phylogenetic relationship. Arch Microbiol 164: 16-23.

Jones RD, Morita R. (1985). Low-temperature growth and whole cell kinetics of a marine ammonium oxidizer. Mar Ecol Prog Ser 21: 239-243.

Jones RD, Prahl FG. (1985). Lipid composition of a marine ammonium oxidizer grown at 5 and $25^{\circ} \mathrm{C}$. Mar Ecol Prog Ser 26: 157-159. 
Kobabe S, Wagner D, Pfeiffer E-M. (2004). Characterization of microbial composition of Siberian tundra soil by fluorescence in situ hybridization. FEMS Microbiol Ecol 50: 13-23.

Könneke M, Bernhard AE, De La Torre JR, Walker CB, Waterbury J, Stahl DA. (2005). Isolation of an autotrophic ammonia-oxidizing marine archaeon. Nature 437: 543-546.

Lane DJ. (1991). 16S/23S rRNA sequencing. In: Stackebrandt E, Goodfellow M (eds). Nucleic Acid Techniques in Bacterial Systematics. Academic Press: Chichester, UK, pp 115-175.

Lebedeva EV, Alawi M, Fiencke C, Namsaraev B, Bock E, Spieck E. (2005). Moderately thermophilic nitrifying bacteria from a hot spring of the Baikal rift zone. FEMS Microbiol Ecol 54: 297-306.

Lebedeva E, Soina V. (1994). Nitrifying bacteria as a promising group for paleoecological investigations in the permafrost. In: Gilichinsky DA (ed). Viable Microorganisms in Permafrost. First International Conference on Cryopedology and Global Change. Russian Academy of Sciences Pushino Research Centre, ISBN 5-206-10586-6, pp 74-82.

Liebner S, Wagner D. (2007). Abundance, distribution and potential activity of methane oxidizing bacteria in permafrost soils from the Lena Delta, Siberia. Environ Microbiol 9: 107-117.

Lipski A, Spieck E, Makolla A, Altendorf K. (2001). Fatty acid profiles of nitrite-oxidizing bacteria reflect their phylogenetic heterogeneity. Syst Appl Microbiol 24: 377-384.

Ludwig W, Strunk O, Westram R, Richter L, Meier H, Yadhu K et al. (2004). ARB: a software environment for sequence data. Nucleic Acids Res 32: 1363-1371.

Manz W, Amann R, Ludwig W, Wagner M, Schleifer K-H. (1992). Phylogenetic oligodeoxynucleotide probes for the major subclasses of proteobacteria: problems and solutions. Syst Appl Microbiol 15: 593-600.

Meincke M, Bock E, Kastrau D, Kroneck PMH. (1992). Nitrite oxidoreductase from Nitrobacter hamburgensis: redox centers and their catalytic role. Arch Microbiol 158: 127-131.

Murray RG, Stackebrandt E. (1995). Taxonomic note: implementation of the provisional status Candidatus for incompletely described procaryotes. Int $J$ Syst Bacteriol 45: 186-187.

Muyzer G, Brinkhoff T, Nübel U, Santegoeds C, Schäfer H, Wawer C. (1998). Denaturing gradient gel electrophoresis (DGGE) in microbial ecology. Mol Microbial Ecol Manual 3.4.4: 1-27.

Philips S, Laanbroek HJ, Verstraete W. (2002). Origin, causes, and effects of increased nitrite concentrations in aquatic environments. Rev Environ Sci Biotechnol 1: 115-141.

Ponder M, Gilmour SJ, Bergholz PW, Mindock CA, Hollinsworth R, Thomashow et al. (2005). Characterization of potential stress responses in ancient Siberian permafrost psychroactive bacteria. FEMS Microbiol Ecol 53: 103-115.

Schwarz JI, Eckert W, Conrad R. (2007). Community structure of Archaea and Bacteria in a profundal lake sediment Lake Kinneret (Israel). Syst Appl Microbiol 30: $239-254$.

Skidmore M, Anderson SP, Sharp M, Foght J, Lanoil BD. (2005). Comparison of microbial community compositions of two subglacial environments reveals a possible role for microbes in chemical weathering processes. Appl Environ Microbiol 71: 6986-6997.

Spieck E, Bock E. (2005). The lithoautotrophic nitriteoxidizing bacteria. In: Garrity G, Brenner DJ, Krieg NR, Staley JT (eds). Bergey's Manual of Systematic Bacteriology, 2nd edn. Springer-Verlag: New York, NY, pp 149-153.

Spieck E, Hartwig C, McCormack I, Maixner F, Wagner M, Lipski A et al. (2006). Selective enrichment and molecular characterisation of a previously uncultured Nitrospira-like bacterium from activated sludge. Environ Microbiol 8: 405-415.

Steinmüller W, Bock E. (1976). Growth of Nitrobacter in the presence of organic matter; I. Mixotrophic growth. Arch Microbiol 108: 299-304.

Wagner D, Lipski A, Embacher A, Gattinger A. (2005). Methane fluxes in permafrost habitats of the Lena Delta: effects of microbial community structure and organic matter quality. Environ Microbiol 7: 1582-1592.

Wagner D, Spieck E, Pfeiffer E-M, Bock E. (2001). Microbial life in terrestrial permafrost: Methanogenesis and nitrification in gelisols as potentials for exobiological processes. In: Horneck G, BaumstarkKhan C (eds.) Astrobiologie-the Quest for the Conditions of Life. Springer-Verlag: Berlin, NY, pp 143-159.

Watson SW, Bock E, Valois FW, Waterbury JB, Schlosser U. (1986). Nitrospira marina gen. nov. sp. nov: a chemolithotrophic nitrite-oxidizing bacterium. Arch Microbiol 144: 1-7.

Watson SW, Bock E, Harms H, Koops H-P, Hooper AB. (1989). Nitrifying bacteria. In: Staley JT, Bryant MP, Pfennig N, Holt JG (eds). Bergey's Manual of Systematic Bacteriology, 1st edn, Vol. 3. The Williams \& Wilkins Co: Baltimore, MD, pp 1808-1834.

Zhou J, Davey ME, Figuera JB, Rivkina E, Gilichinsky D, Tiedje JM. (1997). Phylogenetic diversity of a bacterial community determined from Siberian tundra soil DNA. Microbiology 143: 3913-3919. 